УДК $630 * .865 .1+661.183 .123 .2$

\title{
ВЛИЯНИЕ ПРИРОДЫ КИСЛОТНОГО РЕАГЕНТА НА ВЫХОД И СВОЙСТВА КАТИОНИТОВ, ПОЛУЧЕННЫХ ИЗ ДРЕВЕСНЫХ ОПИЛОК
}

\author{
() И.П. Дейнеко ", И.С. Круглова, И.В. Дейнеко \\ Санкт-Петербургский государственный лесотехнический университет \\ им. С.М. Кирова, Институтский пер., 5, Санкт-Петербург, 194021 (Россия), \\ e-mail: ipdeineko@mail.ru
}

Изучено влияние природы кислотного реагента $\left(\mathrm{H}_{2} \mathrm{SO}_{4}, \mathrm{HClO}_{4}, 4-\mathrm{CH}_{3} \mathrm{C}_{6} \mathrm{H}_{4} \mathrm{SO}_{3} \mathrm{H}, \mathrm{ClCH}_{2} \mathrm{COOH}, \mathrm{H}_{3} \mathrm{PO}_{4}\right)$ на выход и сорбционные свойства полученных из сосновых опилок катионитов. Наиболее высокий выход продукта наблюдается при использовании фосфорной кислоты. Катиониты содержат сильнокислотные и слабокислотные функциональные группы; суммарная емкость по катиону $\mathrm{Na}^{+}$отдельных образцов достигает 2 ммоль/г. Сорбенты, полученные с использованием серной, хлорной и фосфорной кислот, имеют высокое сродство к катионам $\mathrm{Cd}^{2+}$ и $\mathrm{Pb}^{2+}$; емкость по этим катионам находится в интервале $1,0-1,5$ ммоль/г.

Ключевые слова: опилки, кислоты, катиониты, выход, сильнокислотные группы, слабокислотные группы, сорбция, кадмий, цинк, свинец.

\section{Введение}

Обработка древесных опилок водным раствором серной кислоты с отгонкой в ходе процесса воды приводит к образованию нерастворимого в органических растворителях и водных растворах щелочи и кислоты продукта, проявляющего катионообменные свойства $[1,2]$. При этом в получаемом таким образом катионите присутствуют как сильнокислотные, так и слабокислотные группы [2]. Образование сильнокислотных ионогенных центров происходит в результате введения в нерастворимую сетчатую матрицу продукта сульфоновокислых групп, что связано со способностью серной кислоты выступать в роли не только катализатора, но и реагента. Слабокислотные группы, мольная доля которых достигает 80\%, представлены карбоксильными и фенольными гидроксильными группами [3], которые образуются из компонентов древесины в результате кислотно-каталитических реакций.

Наличие большого количества слабокислотных групп, проявляющих электронодонорные свойства, указывает на возможность применения получаемых сорбентов в качестве комплексообразующих ионитов [4]. Однако при использовании серной кислоты выход сорбента невысок вследствие образования из компонентов древесины значительного количества растворимых соединений, удаляющихся из продукта при промывке его водой и водно-щелочным раствором. Поскольку образование слабокислотных групп обусловлено кислотно-каталитическими реакциями, представляется, что для получения слабокислотных катионитов, помимо серной кислоты, можно использовать и другие кислотные реагенты.

В данной работе приведены результаты исследования влияния природы кислотного реагента на выход и сорбционные свойства катионитов, полученных из сосновых опилок.

\section{Экспериментальная часть}

В качества исходного сырья использовали сосновые опилки (0,25-0,5 мм); содержание экстрактив-

Дейнеко Иван Павлович - доктор химических наук, профессор, тел.: (812) 550-06-98,

e-mail: ipdeineko@mail.ru

Круглова Ирина Сергеевна - студентка

Дейнеко Инна Валерьевна - доцент, кандидат

химических наук ных веществ (экстрагент - этоксиэтан) составляло $5,22 \%$, лигнина $-26,7 \%$.

Опыты проводили в соответствии с ранее разработанной методикой [1]. Общая схема эксперимента приведена на рисунке.

\footnotetext{
* Автор, с которым следует вести переписку.
} 


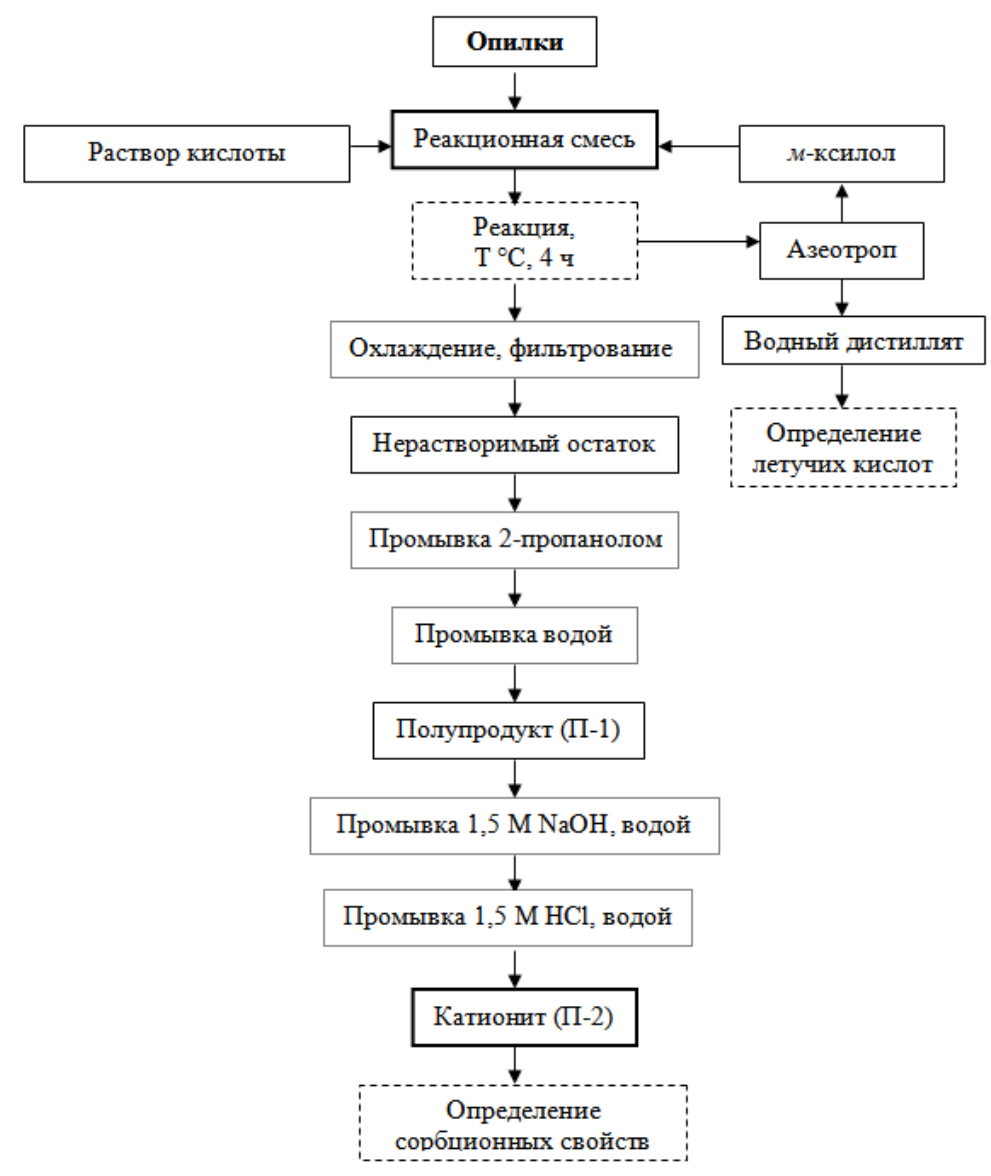

Общая схема проведения эксперимента

В качестве исходной реакционной среды использовали 0,1 молярные водные растворы неорганических (серная кислота - СК1, хлорная кислота - ХК, ортофосфорная кислота - ФК) и органических ( $n$-толуолсульфокислота - ТСК, монохлоруксусная кислота - ХУК) кислот. Для обеспечения равномерного распределения кислоты в сырье навеску опилок (9-10 г) помещали в избыток раствора $\left(60 \mathrm{~cm}^{3}\right)$. С целью уточнения влияния концентрации кислоты на выход и свойства сорбентов в одном опыте был также использован 0,2 молярный раствор серной кислоты (СК2), свободно стекающий избыток которого отделяли. После пропитки сырья к реакционной смеси добавляли в качестве антренера $M$-ксилол $\left(70 \mathrm{~cm}^{3}\right)$ и отгоняли избыточную и реакционную воду в виде азеотропа с растворителем. Общая продолжительность процесса составляла 4 ч; при этом основная часть воды отгонялась примерно за 1 ч.

За максимальную температуру обработки принимали температуру кипения растворителя $\left(139{ }^{\circ} \mathrm{C}\right)$. По окончании реакции и охлаждения реакционной смеси нерастворившийся материал отделяли от антренера и экстрагировали из твердого остатка низкомолекулярные продукты изопропиловым спиртом, а затем отмывали от остаточных количеств кислоты и гидрофильных веществ водой до нейтральной реакции среды и обесцвечивания элюата. После высушивания полупродукта (П-1) при $70{ }^{\circ} \mathrm{C}$ до постоянной массы определяли его выход.

Для удаления из продукта веществ, растворимых в щелочи, П-1 промывали в колонке раствором $1,5 \mathrm{M} \mathrm{NaOH}$ до обесцвечивания элюата. Далее сорбент отмывали от щелочи водой, переводили его в $\mathrm{H}^{+}$-форму, обрабатывая $1,5 \mathrm{M} \mathrm{HCl}$, после чего промывали водой до нейтрального $\mathrm{pH}$, высушивали в вакуум-эксикаторе над $\mathrm{P}_{2} \mathrm{O}_{5}$ до постоянной массы и определяли выход катионита (П-2). По разности между выходами П-1 и П-2 рассчитывали количество веществ, растворимых в щелочи.

В водном дистилляте, отобранном в ходе опыта, проводили количественное определение кислот, для чего титровали аликвотную часть раствора 0,1 н $\mathrm{NaOH}$ в присутствии фенолфталеина, и поскольку, как было показано ранее [7], там содержится преимущественно уксусная кислота, содержание кислот приведено в расчете на уксусную кислоту. 
Чтобы оценить долю ионогенных групп, присутствующих в исходной древесине и появляющихся в результате обработки при комнатной температуре 2-пропанолом и растворами кислоты и щелочи, один образец опилок (10 г) был подвергнут таким же обработкам, как и исследуемые образцы, за исключением первой стадии (контрольный образец - КО), т.е. без нагревания с раствором кислоты.

В полученных сорбентах (П-2) определяли содержание сильнокислотных и слабокислотных групп динамическим методом. Для этого в небольшую фильтровальную воронку помещали около 1 г катионита, заливали $30 \mathrm{~cm}^{3}$ дистиллированной воды и оставляли катионит набухать в течение суток. Через набухший катионит пропускали последовательно по $100 \mathrm{~cm}^{3}$ 0,5 н NaCl, 0,5 н $\mathrm{CH}_{3} \mathrm{COONa}$ и 0,1 н $\mathrm{NaOH}$ со скоростью приблизительно 1,6 cм³/мин (т.е. в течение примерно 1 ч). При этом после пропускания первых двух растворов катионит промывали $50 \mathrm{~cm}^{3}$, а после пропускания раствора $\mathrm{NaOH}-200 \mathrm{~cm}^{3}$ дистиллированной воды, собирая элюаты после пропускания каждого раствора и дистиллированной воды для отмывки от него катионита в отдельные колбы и замеряя объем каждого суммарного раствора.

Расчет содержания сильно- и слабокислотных групп осуществляли следующим образом.

1. Сильнокислотные группьл. В аликвотной части элюата $\left(25 \mathrm{~cm}^{3}\right)$ после пропускания через катионит раствора $\mathrm{NaCl}$ определяли количество выделившейся кислоты титрованием 0,1 н $\mathrm{NaOH}$ в присутствии метилоранжа и по полученным результатам вычисляли содержание сильнокислотных групп катионита (ммоль/г) по формуле:

$$
E_{S A}=\frac{V_{O} V_{T} 0,1}{V_{A} m},
$$

где $V_{O}$ - общий объем элюата, $\mathrm{cm}^{3} ; V_{T}$ - объем титранта, пошедший на титрование аликвотной части элюата, $\mathrm{cm}^{3} ; 0,1$ - коэффициент пересчета количества щелочи, выраженного в см $^{3}$ в ммоль; $V_{A}-$ объем титруемой аликвотной части элюата, $\mathrm{cm}^{3} ; m$ - масса навески катионита, г.

2. Карбоксильные группы. В аликвотной части элюата $\left(10 \mathrm{~cm}^{3}\right)$ после пропускания через катионит раствора $\mathrm{CH}_{3} \mathrm{COONa}$ определяли количество выделившейся кислоты титрованием 0,1 н $\mathrm{NaOH}$ в присутствии фенолфталеина. Содержание -СООН-групп в катионите (ммоль/г) рассчитывали по формуле, используемой для расчета содержания сильнокислотных групп.

3. Фенольные груnпь. В аликвотной части элюата $\left(10 \mathrm{~cm}^{3}\right)$ после пропускания через катионит раствора $\mathrm{NaOH}$ определяли остаточное количество щелочи, проводя титрование $0,1 \mathrm{H} \mathrm{HCl}$ в присутствии фенолфталеина, и затем рассчитывали содержание -ОН-групп в катионите (ммоль/г) по формуле:

$$
E_{O H}=\frac{\left(100-\frac{V_{O} V_{T}}{V_{A}}\right) 0,1}{m},
$$

где 100 - объем 0,1 н $\mathrm{NaOH}$, пропускаемого через катионит, мл; $V_{O}$ - общий объем элюата, см³ $V_{T}-$ объем титранта, пошедший на титрование аликвотной части элюата, см$^{3} ; V_{A}-$ аликвотная часть элюата, см ${ }^{3} ; 0,1-$ коэффициент пересчета количества щелочи, выраженного в мл в ммоль; $m$ - масса навески катионита, г.

Определение сорбционных свойств катионитов по ионам $\mathrm{Pb}^{2+}, \mathrm{Cd}^{2+}, \mathrm{Zn}^{2+}$. Для изучения сорбционных свойств использовали продажные препараты ацетатов свинца, кадмия и цинка квалификации «чда»; определение концентрации катионов осуществляли, беря за основу стандартные методики $[5,6]$.

В колбу помещали 0,4-0,5 г катионита и пропитывали образец $5 \mathrm{~cm}^{3}$ дистиллированной воды в течение 2 ч. После набухания в колбу добавляли по $50 \mathrm{~cm}^{3} 0,1 \mathrm{M}$ растворов $\mathrm{Pb}\left(\mathrm{CH}_{3} \mathrm{COO}\right)_{2}, \mathrm{Cd}\left(\mathrm{CH} \mathrm{COO}_{2} \quad\right.$ или $\mathrm{Zn}\left(\mathrm{CH}_{3} \mathrm{COO}\right)_{2}$ и оставляли образцы в растворах солей на сутки, периодически перемешивая. Затем раствор отделяли от катионита с помощью пористого стеклянного фильтра. В исходных растворах и в полученных фильтратах измеряли рН с помощью иономера И-120.1. Количество сорбированных катионитом ионов металлов находили по разности между концентрацией ионов в начальном растворе и в фильтрате, полученном после взаимодействия с катионитом. Определение концентраций проводили титриметрическим методом.

При титровании исходного раствора к нему добавляли воду с таким расчетом, чтобы соблюдалось соотношение, как и при анализе образцов, $-10: 1$. 
Определение концентраций ионов $\mathrm{Cd}$, $\mathrm{Zn}$, Pb и расчет сорбциионных свойств.

1. Для определения концентрации ионов $\mathrm{Cd}$ к аликвотной части $\left(3 \mathrm{~cm}^{3}\right)$ анализируемого раствора прибавляли $5 \mathrm{~cm}^{3}$ ацетатного буферного раствора, $10 \mathrm{~cm}^{3} \mathrm{C}_{2} \mathrm{H}_{5} \mathrm{OH}, 1 \mathrm{~cm}^{3}$ индикатора дитизона, растворенного в ацетоне $\left(25 \mathrm{mг} / 100 \mathrm{~cm}^{3}\right)$, и титровали 0,05 М раствором ЭДТА до перехода окраски индикатора из оранжевой в серую.

Установление титра раствора ЭДТА осуществляли по стандартному 0,1 н раствору $\mathrm{KMnO}_{4}$.

Исходя из молекулярной массы кадмия рассчитывали его количество $\left(\mathrm{X}, \mathrm{Mг} / \mathrm{cm}^{3}\right)$, связываемое $1 \mathrm{~cm}^{3}$ раствора ЭДТА:

$$
X=M_{T} \cdot M_{C d}
$$

где $M_{T}$ - молярная концентрация раствора ЭДТА, моль/см${ }^{3} ; M_{C d}-$ молекулярная масса $\mathrm{Cd}$, мг/моль.

Затем вычисляли сорбционную емкость катионита по Сd (Y, мг/ г) по формуле:

$$
E_{C d}=\frac{\left(V^{O}-V^{A}\right) V_{O} X}{V_{A} m},
$$

где $V^{O}$ - объем ЭДТА $\left(\mathrm{cm}^{3}\right)$, пошедший на титрование аликвотной части исходного раствора ацетата кадмия; $V^{A}$ - объем ЭДТА $\left(\mathrm{cm}^{3}\right)$, пошедший на титрование аликвотной части фильтрата, полученного после взаимодействия с катионитом; $V_{O}$ - суммарный объем $\left(\mathrm{cm}^{3}\right)$ раствора соли и дистиллированной воды, использованной для набухания катионита; $V_{A}$ - объем аликвотной части анализируемого раствора $\left(\mathrm{cm}^{3}\right)$; $m$ - масса навески катионита (г).

2. Определение концентрации ионов $\mathrm{Zn}$ в растворах и расчет сорбционной способности катионита по этому металлу проводили аналогично методике, приведенной для определения сорбционной способности по Сd.

3. Определение концентрации ионов $\mathrm{Pb}$ в растворах проводили следующим образом: аликвотную часть (4,7 $\left.\mathrm{cm}^{3}\right)$ анализируемого раствора разбавляли $25 \mathrm{~cm}^{3}$ дистиллированной воды, добавляли $3 \mathrm{~cm}^{3}$ ацетатного буферного раствора, 1 см $^{3}$ индикатора ксиленолового оранжевого $(0,1 \%$-ный слабощелочной водный раствор) и титровали 0,05 М раствором ЭДТА до перехода малиновой окраски индикатора в лимонножелтую. Расчет проводился по формулам, аналогичным использованным для расчета сорбционной активности по ионам $\mathrm{Cd}$.

\section{Обсуждение результатов}

При обработке древесного вещества разбавленным водным раствором серной кислоты с отгонкой в ходе процесса воды протекают как реакции деструкции, так и процессы конденсации. По мере снижения доли воды в реакционной смеси усиливается роль реакций конденсации, что приводит к образованию в качестве конечного продукта твердого, не растворимого в водных системах и в органических растворителях остатка. Важным свойством получаемого продукта является наличие в нем ионогенных групп, способных вступать в обменные реакции с катионами. Поэтому представляется перспективным использовать эти продукты как катиониты. При применении в качестве кислотного катализатора серной кислоты одновременно с ее каталитическим действием происходит и введение в формирующуюся сетчатую матрицу сульфоновокислых групп. Наряду с этими сильнокислотными группами, в продукте присутствуют и слабокислотные реакционные центры, доля которых даже при достаточно большом расходе серной кислоты заметно выше, чем доля сильнокислотных групп [7]. Как было выяснено [3], слабокислотные центры в получаемых катионообменниках представлены карбоксильными и енольными, в том числе и фенольными, группами. Поскольку карбоксильные и гидроксильные группы обладают комплексообразующими свойствами, получаемые из древесины катиониты могут представлять практический интерес как сорбенты для удаления из растворов ионов поливалентных металлов. Однако при использовании в качестве реагента серной кислоты в результате образования сульфоновокислых групп значительная часть первично образующегося продукта растворяется при его обработке щелочным раствором, и вследствие этого выход катионита сравнительно невысок. Очевидно, что применение других кислотных реагентов должно привести к повышению выхода целевого продукта вследствие исключения возможности образования сильнополярных сульфоновокислых групп. Результаты опытов, приведенные в таблице 1, подтверждают данное предположение. 
Таблица 1. Выход продуктов, образующихся при кислотной обработке сосновых опилок

\begin{tabular}{c|c|c|c|c|c}
\hline \multirow{2}{*}{ Реагент } & \multirow{2}{*}{ рК кислоты [8] } & \multirow{2}{*}{$\begin{array}{c}\text { Расход, } \\
\text { \% от а.с.д. }\end{array}$} & \multicolumn{3}{|c}{ Выход продуктов, \% от а.с.д. } \\
\cline { 3 - 5 } & & - & 81,0 & щелочерастворимые вещества & летучие кислоты \\
\hline КО & - & 5,9 & 59,5 & 21,5 & $\ldots$ \\
СК1 & $-3,1$ & 9,3 & 60,9 & 16,1 & $\ldots$ \\
СК2 & & 6,4 & 64,6 & 12,9 & 3,7 \\
ХК & -8 & 11,1 & 75,1 & 8,1 & 2,0 \\
ТСК & $-2,7$ & 6,3 & 82,6 & 4,7 & 1,4 \\
ФК & 2,12 & 6,1 & 82,1 & 10,5 & 1,2 \\
ХУК & 2,87 &
\end{tabular}

Как видно по сравнению с серной кислотой, использование других кислотных катализаторов приводит к образованию продукта с существенно более высоким выходом. Максимальный выход сорбента наблюдается для фосфорной кислоты. В случае применения толуолсульфокислоты, являющейся более сильной кислотой, выход сорбента ниже, что связано с более активным протеканием реакций гидролитической деструкции компонентов древесины. Действие хлорной кислоты, проявляющей наиболее сильные кислотные свойства, приводит к еще более ощутимому падению выхода сорбента. Помимо реакций деструкции, действие хлорной кислоты сопровождается и окислительными превращениями, на что, в частности, указывает образование большего, по сравнению с опытами, выполненными с другими кислотами, количества летучих кислот. В присутствии монохлоруксусной кислоты количество образующегося продукта примерно равно количеству сорбента, полученного с фосфорной кислотой. Однако, в отличие от опытов с фосфорной кислотой, при использовании монохлоруксусной кислоты получается значительно больше щелочерастворимых веществ. Поскольку рК этих кислот близки и их гидролитическое действие должно быть не очень велико, деструкция компонентов древесины в их присутствии, очевидно, происходит в незначительной степени, и в случае образца, полученного с монохлоруксусной кислотой, при обработке щелочью не растворимого в реакционной смеси вещества из него удаляется значительное количество гемицеллюлоз. В то же самое время названные кислоты склонны к образованию сложноэфирной связи, и фосфорная кислота, являясь, в отличие от монохлоруксусной, трехосновной кислотой, может образовывать три такие связи, тем самым выступая в роли сшивающего реагента, включающего олигосахариды в сетчатую матрицу нерастворимого продукта.

Обращает на себя внимание то, что при использовании серной кислоты более высокой концентрации (опыт СК2) количество образующихся щелочерастворимых веществ ниже, чем в опыте с меньшим расходом реагента. Относительно небольшое повышение выхода катионита по сравнению с опытом СК1 здесь может быть объяснено более активным протеканием реакций дегидратации.

Изучение ионообменных свойств полученных катионитов показало существенные различия в количественном содержании отдельных катионообменных групп.

Как видно из приведенных в таблице 2 данных, все образцы имеют сильнокислотные группы. Если в случае сорбентов, полученных с серной кислотой, этими группами, как отмечалось, являются сульфоновокислые группы, то в случае других образцов сильнокислотные свойства, по-видимому, проявляют карбоксильные и енольные группы, имеющие в качестве соседних заместителей электроноакцепторные группировки, повышающие кислотные свойства названных функциональных групп [9]. Существенно более высокое содержание сильнокислотных групп характерно для сорбента, полученного с фосфорной кислотой, что, по-видимому, в значительной степени связано с введением в сетчатую матрицу фосфорнокислых групп, сила которых повышается также вследствие присутствия электроноакцепторных заместителей, находящихся в сопряжении со сложноэфирными связями образующихся фосфатов.

Таблица 2. Ионообменные свойства катионитов, ммоль/г

\begin{tabular}{c|c|c|c|c}
\hline \multirow{2}{*}{ Катионит } & Сильнокислотные & \multicolumn{2}{|c|}{ Сумаа кислотных } \\
\cline { 3 - 4 } & группы & карбоксильные & енольные & 0,46 \\
\hline КО & 0,12 & 0,14 & 0,20 & 0,96 \\
СК1 & 0,33 & 0,23 & 0,40 & 1,96 \\
СК2 & 0,32 & 0,99 & 0,65 & 1,95 \\
ХК & 0,13 & 0,72 & 1,10 & 0,80 \\
ТСК & 0,14 & 0,43 & 0,23 & 2,22 \\
ФК & 0,83 & 0,89 & 0,50 & 0,48 \\
ХУК & 0,13 & 0,15 & 0,20 & \\
\hline
\end{tabular}


Во всех полученных катионитах наблюдается присутствие карбоксильных групп. Как известно, некоторые компоненты древесины (полиурониды и лигнин) содержат карбоксильные группы, чем и объясняется их присутствие в контрольном образце. Более высокое по сравнению с контрольным образцом содержание названных групп почти во всех сорбентах, за исключением продукта, полученного с монохлоруксусной кислотой, по-видимому, объясняется протеканием окислительно-восстановительных реакций с участием активных интермедиатов, образующихся при гидролитических превращениях компонентов древесины. Однако нельзя исключить проявления окислительных свойств в условиях эксперимента и у отдельных использованных реагентов, в частности у серной и, как отмечалось, у хлорной кислот.

Повышение количества енольных (фенольных) кислотных групп у препаратов после кислотной обработки можно объяснить как разрывом простых эфирных связей в макромолекуле лигнина, так и протеканием реакций дегидратации в диольных группировках полисахаридов. Относительно невысокое содержание енольных гидроксильных групп у образца, полученного в присутствии толуолсульфокислоты, вероятно, связано с трудностью проникновения сравнительно большой молекулы реагента к реакционным центрам. Это объясняет и относительно невысокое суммарное содержание кислотных центров в рассматриваемом образце.

Образец, полученный с монохлоруксусной кислотой, по составу кислотных групп почти не отличается от контрольного образца, что подтверждает сделанное выше заключение о не очень значительных структурных изменениях компонентов древесины при обработке этим реагентом.

При сравнении сорбентов, полученных при использовании серной кислоты разной концентрации, видно, что в случае СК2 содержание кислотных групп существенно выше, и, учитывая меньшее количество щелочерастворимых веществ, можно сделать вывод о повышении роли реакций конденсации и функционализации с одновременным снижением роли реакций деструкции полимеров древесного вещества при увеличении концентрации серной кислоты.

Присутствие значительного количества слабокислотных групп, обладающих комплексообразующими свойствами, указывает на возможность их применения для удаления из растворов ионов тяжелых металлов. Поэтому была изучена сорбция полученными катионитами таких токсичных ионов металлов, как катионы свинца, кадмия и цинка.

Результаты по сорбции ионов кадмия приведены в таблице 3. Полученные экспериментальные данные свидетельствуют о разной степени сродства сорбентов к этому катиону. Емкость образца, полученного с монохлоруксусной кислотой, оказалась примерно такой же, как и у контрольного образца, что объясняется низким содержанием ионогенных групп. Неожиданным оказалась сравнительно невысокая емкость к кадмию сорбента, полученного при использовании в качестве катализатора фосфорной кислоты, имеющего достаточно высокое содержание ионогенных центров. Как было выяснено, это связано с недостаточной гидрофильностью образца, препятствующей проникновению молекул воды внутрь сорбента. При использовании для набухания водно-спиртового $(3: 2)$ раствора получены данные, более объективно отражающие его сорбционные свойства (см. табл. 3). Высокое сродство к катионам кадмия наблюдается для сорбентов, полученных с серной и хлорной кислотами. Существенное снижение рН в фильтратах свидетельствует о том, что катионы взаимодействуют с сильнокислотными группами. Однако, учитывая, что эквивалент кадмия в два раза меньше его молекулярной массы, сравнение данных по содержанию кислотных групп (см. табл. 2) и емкости сорбентов по иону кадмия свидетельствует об участии в сорбции и слабокислотных центров за счет образования координационных связей.

Сходная картина, хотя и с некоторыми отличиями, наблюдается и в случае сорбции ионов цинка (табл. 4). Наибольшую емкость здесь также проявляют сорбенты, полученные с серной, хлорной и фосфорной кислотами. Однако в этом случае емкость сорбентов несколько ниже, чем при сорбции ионов кадмия. Это связано с тем, что в случае образования координационной связи важное значение имеет расстояние между функциональными группами лигандов. Поскольку ион цинка имеет меньший радиус $(0,074$ нм $)$, чем ион кадмия (0,095 нм) [10], не все функциональные группы располагаются на оптимальном для образования комплекса с цинком расстоянии.

Таблица 3. Сорбция ионов кадмия катионитами

\begin{tabular}{c|c|c|c|c|c|c|c}
\hline Параметры & КО & СК1 & СК2 & ХК & ТСК & ФК & ХУК \\
\hline мГ/Г & 21,4 & 125 & 110 & 109 & 30,8 & $41,7(113)$ & 20,8 \\
ммоль/Г & 0,19 & 1,1 & 0,95 & 0,95 & 0,28 & $0,37(1,0)$ & 0,18 \\
рН фильтрата & 6,5 & $\ldots$ & 5,6 & 5,6 & 5,4 & $5,9(5,5)$ & 6,4 \\
\hline
\end{tabular}

Примечания: ${ }^{*} \mathrm{pH}$ исходного раствора ацетата кадмия $-7,3 ;{ }^{* *}$ в скобках приведены данные, полученные при набухании образца в водно-спиртовом растворе. 
Таблица 4. Сорбция катионитами ионов цинка

\begin{tabular}{c|c|c|c|c|c|c|c}
\hline Параметры & КО & СК1 & СК2 & ХК & ТСК & ФК & ХУК \\
\hline мГ/Г & 12,6 & 39,7 & 50,7 & 49,6 & 24,1 & $24,5(53,7)$ & 24,4 \\
ммоль/Г & 0,19 & 0,61 & 0,77 & 0,76 & 0,37 & $0,37(0,82)$ & 0,37 \\
рН фильтрата & 6,5 & $\ldots$ & 5,8 & 5,9 & 6,2 & $6,0(5,6)$ & 6,5 \\
\hline
\end{tabular}

Примечания: * $\mathrm{pH}$ исходного раствора ацетата цинка $-6,6 ;{ }^{* *}$ в скобках приведены данные, полученные при набухании образца в водно-спиртовом растворе.

Учитывая, что при образовании комплексов с ионами металлов связывается большее, чем необходимо для нейтрализации заряда ионов число лигандов, сделана попытка определить, участвуют ли в комплексообразовании низкомолекулярные соединения (ионы), т.е. образовывается ли внутренняя сфера комплексов только за счет функциональных групп сорбента или в роли лигандов выступают и частицы, присутствующие в растворе. Для этого при изучении сорбции ионов свинца образцы после выдерживания в растворе соли и отделения фильтрата тщательно отмывались водой от следов несорбированной соли, и после высушивания $\left(103 \pm 2{ }^{\circ} \mathrm{C}\right)$ в них определялся прирост массы, обусловленный сорбцией катиона. Данные, приведенные в таблице 5, не дают вполне однозначного ответа на этот вопрос. У контрольного образца и сорбентов, полученных с использованием серной кислоты и толуолсульфокислоты, прирост массы образцов после сорбции оказался больше массы сорбированного катиона. Поэтому в этих случаях можно говорить об участии в образовании комплексов не только полярных группировок сорбентов, но и ацетат-анионов и/или молекул воды. У образцов же, полученных в присутствии хлорной, фосфорной и монохлоруксусной кислот, прирост массы несколько меньше количества сорбированного катиона. Однако здесь пока преждевременно делать вывод об отсутствии координации катионов с низкомолекулярными соединениями. Меньшие значения прироста массы можно объяснить и неустойчивостью катионитов при повышенной температуре, использованной для высушивания образцов. В дальнейшем этот вопрос требует более обстоятельного изучения.

Как и при сорбции ионов кадмия и цинка, образцы, полученные с помощью серной и хлорной кислот, показывают достаточно высокое сродство к катионам свинца, сравнимое со сродством к ионам кадмия. Из этого следует вывод, что селективность названных сорбентов в ряду изученных ионов металлов невелика. Для образца же, полученного с фосфорной кислотой, наблюдается некоторая селективность по отношению к ионам свинца; емкость по свинцу в полтора раза выше, чем емкость по ионам кадмия, и в два раза превышает емкость сорбента к ионам цинка. Данный факт можно объяснить тем, что участвующие в комплексообразовании группировки сорбента находятся в благоприятном для взаимодействия с достаточно крупным двухзарядным катионом свинца (0,119 нм) [10] положении.

Таблица 5. Сорбция катионитами ионов свинца

\begin{tabular}{c|c|c|c|c|c|c}
\hline Параметры & КО & СК2 & ХК & ТСК & ФК & ХУК \\
\hline мг/Г & 24,2 & 242 & 218 & 121 & $242(314)$ & 72,5 \\
ммоль/Г & 0,12 & 1,2 & 1 & 0,58 & $1,2(1,5)$ & 0,35 \\
рН фильтрата & 5,9 & 5,3 & 5,3 & 5,6 & $5,2(5,2)$ & 5,8 \\
прирост массы, мг/Г & 47,5 & 353 & 195 & 158 & $217(248)$ & 68,7 \\
\hline
\end{tabular}

Примечания: ${ }^{*} \mathrm{pH}$ исходного раствора ацетата свинца - 6,3; ${ }^{* *}$ в скобках приведены данные, полученные при набухании образца в водно-спиртовом растворе.

\section{Выводы}

1. При обработке древесных опилок 0,1 М водными растворами кислот с отгонкой в ходе процесса воды получаются катиониты, выход которых в зависимости от природы кислотного катализатора возрастает в ряду (\%): $\mathrm{H}_{2} \mathrm{SO}_{4}(59,5), \mathrm{HClO}_{4}(64,6), 4-\mathrm{CH}_{3} \mathrm{C}_{6} \mathrm{H}_{4} \mathrm{SO}_{3} \mathrm{H}(75,1), \mathrm{ClCH}_{2} \mathrm{COOH}(82,1), \mathrm{H}_{3} \mathrm{PO}_{4}(82,6)$.

2. Катиониты содержат сильнокислотные и слабокислотные ионогенные группы. Наибольшую суммарную емкость (порядка 2 ммоль/г) имеют катиониты, полученные при использовании серной, хлорной и фосфорной кислот.

3. Катиониты, полученные с использованием серной, хлорной и фосфорной кислот, имеют достаточно высокую емкость при сорбции двухвалентных катионов кадмия и свинца (1,0-1,5 ммоль/г) и меньшую емкость при сорбции катионов цинка (0,7-0,8 ммоль/г).

4. Катиониты, полученные обработкой опилок минеральными кислотами, можно использовать в качестве сорбентов для удаления из растворов катионов тяжелых металлов. 


\title{
Список литературы
}

1. Дейнеко И.П., Круглова И.С., Дейнеко И.В. Изучение кислотно-каталитических превращений древесины // Известия Санкт-Петербургской лесотехнической академии. 2010. Вып. 190. С. 134-141.

2. Дейнеко И.П., Хакало А.С. Влияние концентрации серной кислоты на свойства катионитов, полученных из древесины // Известия Санкт-Петербургской лесотехнической академии. 2010. Вып. 191. С. 195-201.

3. Дейнеко И.П., Круглова И.С., Дейнеко И.В. Влияние природы кислотного реагента на кислотно-каталитические превращения древесины // Известия Санкт-Петербургской лесотехнической академии. 2011. Вып. 195. С. 172-180.

4. Салдадзе К.М., Копылова-Валова В.Д. Комплексообразующие иониты (комплекситы). М., 1980. 336 с.

5. Шарло Г. Методы аналитической химии. Количественный анализ неорганических соединений. М., 1969. Ч. 2. 1204 с.

6. Юрист И.М., Талмуд М.М. Селективное комплексонометрическое титрование. М., 1993. 232 с.

7. Дейнеко И.П., Хакало А.С., Пранович А.В. Получение катионообменных сорбентов обработкой еловых опилок серной кислотой // Химия растительного сырья. 2011. №4. С. 33-38.

8. Гордон А., Форд Р. Спутник химика. М., 1976. 541 с.

9. Stewart R. The Proton: Application to Organic Chemistry. Orlando, Academic Press, INC. 1985. 313 p.

10. Третьяков Ю.Д., Мартыненко Л.И., Григорьев А.Н., Цивадзе А.Ю. Неорганическая химия. Химия элементов. М., 2007. T. 2. $670 \mathrm{c}$.

Поступило в редакцию 31 декабря 20112.

\begin{abstract}
Deineko I.P., Kruglova I.S., Deineko I.V. INFLUENCE OF THE NATURE OF ACID REAGENTS TO YIELD AND PROPERTIES OF THE CATION EXTENDERS DERIVED FROM SAWDUST

St. Petersburg State Forestry University, Institutskii per. 5, St. Petersburg, 194021 (Russia), e-mail: ipdeineko@mail.ru

Influence of the nature of acid reagents $\left(\mathrm{H}_{2} \mathrm{SO}_{4}, \mathrm{HClO}_{4}, 4-\mathrm{CH}_{3} \mathrm{C}_{6} \mathrm{H}_{4} \mathrm{SO}_{3} \mathrm{H}, \mathrm{ClCH}_{2} \mathrm{COOH}, \mathrm{H}_{3} \mathrm{PO}_{4}\right)$ on yield and sorption properties of cation exchangers derived from pine sawdust has been studied. The highest yield cation exchanger is observed when using phosphoric acid. Cation exchangers contain strong and weakly acid functional groups, the total capacity on the cation $\mathrm{Na}^{+}$of individual samples up to $2 \mathrm{mmol} / \mathrm{g}$. Sorbents obtained by using sulfuric, perchloric and phosphoric acids have a high affinity for cations $\mathrm{Cd}^{2+}$ and $\mathrm{Pb}^{2+}$; capacity for these cations varies in the range of $1,0-1,5 \mathrm{mmol} / \mathrm{g}$.

Keywords: Sawdust, acids, cation exchangers, yield, strong acid groups, weakly acid groups, sorption, cadmium, zinc, lead.
\end{abstract}

\section{References}

1. Deineko I.P., Kruglova I.S., Deineko I.V. Izvestiia Sankt-Peterburgskoi lesotekhnicheskoi akademii, 2010, no. 190, pp. 134-141 (in Russ.).

2. Deineko I.P., Khakalo A.S. Izvestiia Sankt-Peterburgskoi lesotekhnicheskoi akademii, 2010, no. 191, pp. 195-201. (in Russ.).

3. Deineko I.P., Kruglova I.S., Deineko I.V. Izvestiia Sankt-Peterburgskoi lesotekhnicheskoi akademii, 2011, no. 195, pp. 172-180. (in Russ.).

4. Saldadze K.M., Kopylova-Valova V.D. Kompleksoobrazuiushchie ionity (kompleksity). [Chelating resins (kompleksity)]. Moscow, 1980, 336 p. (in Russ.).

5. Sharlo G. Metody analiticheskoi khimii. Kolichestvennyi analiz neorganicheskikh soedinenii. [Methods of analytical chemistry. Quantitative analysis of inorganic compounds]. Moscow, 1969, part. 2, 1204 p. (in Russ.).

6. Iurist I.M., Talmud M.M. Selektivnoe kompleksonometricheskoe titrovanie. [Selective Complexometric titration]. Moscow, 1993, 232 p. (in Russ.).

7. Deineko I.P., Khakalo A.S., Pranovich A.V. Khimiia rastitel'nogo syr'ia, 2011, no. 4, pp. 33-38. (in Russ.).

8. Gordon A., Ford R. Sputnik khimika. [Satellite chemist]. Moscow, 1976, 541 p. (in Russ.).

9. Stewart R. The Proton: Application to Organic Chemistry. Orlando, Academic Press, INC. 1985. 313 p.

10. Tret'iakov Iu.D., Martynenko L.I., Grigor'ev A.N., Tsivadze A.Iu. Neorganicheskaia khimiia. Khimiia elementov. [Inorganic Chemistry. Chemistry of the Elements]. Moscow, 2007, vol. 2, 670 p. (in Russ.). 